\title{
Jean Briggs's Never in Anger as an Ethnography of Experience
}

\section{Susan Pratt Walton}

University of Michigan

\section{Ethnography of experience}

In this paper I re-examine Never in Anger: Portrait of an Eskimo Family (1970) by Jean Briggs. This classic anthropological text is a pioneering attempt to achieve many of the same intellectual and literary goals espoused by the authors of the current ethnographies of experience. By seeking to understand why this book was misunderstood by the scholarly community at the time of its publication, I hope to reveal the kind of unexamined assumptions about the nature of emotions that prevailed in anthropological circles at the time. I will further suggest that Never in Anger offers insights into provocative and fruitful techniques that ethnographers can employ in writing about emotions and life experiences of individuals in other cultures. In several crucial respects, Never in Anger can be regarded as an ethnography of experience: in taking as its subject of enquiry the self, emotions and personhood; in its use of an unusual textual style; in its focus on specific individuals rather than on typified generalizing statements and cultural rules; and in its inclusion of multiple voices and points of view.

In 1986, two major theoretical works in United States anthropology were published: Anthropology as Cultural Critique: An Experimental Moment in the Human Sciences by George E. Marcus and Michael M. J. Fischer, and The Anthropology of Experience, edited by Victor W. Turner and Edward M. Bruner. Both books devoted considerable space to the 'ethnography of experience' (Marcus's and Fischer's term) or the 'anthropology of experience' (Turner's and Bruner's). Though these labels are rather flexible, they both highlight the individual's lived reality, emotions, and concepts of self and personhood as important focal points in many of the new ethnographies.

The notion of the anthropology of experience can best be understood by

Critique of Anthropology (C) 1993 (SAGE, London, Newbury Park and New Delhi), Vol. 13(4): 379-399. 
looking at its history, which draws heavily on the hermeneutic tradition of the German philosopher Wilhem Dilthey (1833-1911). Dilthey wrote that 'reality only exists for us in the facts of consciousness given by inner experience' (quoted in Bruner, 1986: 4). Dilthey grappled with the problem of the seeming impossibility of grasping another's experience. He suggested we 'transcend the narrow sphere of experience by interpreting expressions' (quoted in Turner and Bruner, 1986:5). By 'expressions', Dilthey meant outward objectifications of inner realities, that is, performances, rituals, texts, behaviors, artistic forms and narratives. Dilthey's argument turns on three ontological elements, objective reality (whatever happens 'out there', beyond the confines of interpreting selves), experience (how that reality is perceived and defined by an individual) and expressions (how experience is represented and exteriorized to the outer world).

Victor Turner, who was influenced by Dilthey and also John Dewey, was the first anthropologist to formulate an anthropology of experience (Bruner 1986: 13). He held that cultures are best understood not by looking at the unchanging, the typical or the habitual, but by examining high moments of intense experience in a culture, for these embody 'meanings'. These vital, fulfilling expressions can be aesthetic, involving drama and the other arts, and social, involving rituals, rites and any other major interruptions from routines.

While Turner's anthropology of experience emphasizes aesthetic performances, Marcus's and Fischer's notion of 'ethnography of experience' has a more literary and subjective focus. For Marcus and Fischer, the intricacy, complexity and detail of the knowledge that the ethnographer obtains from the fieldwork experience cannot be adequately conveyed using the traditional language of social science, which is objective and authoritative. What is omitted in traditional accounts is a focus on the particularities of experience of ethnographic subjects. Instead, it is the theories the ethnographer creates to explain those experiences that are typically foregrounded. In the new ethnographies of experience, however, the thoughts, feelings and lived realities of ethnographic subjects attain a central position in the text.

Following this shift, the ethnographer must allow into her/his text several new voices (see Clifford, 1983). Most important are the ethnographic subjects themselves. But informants do not speak in a vacuum. They speak to an ethnographer who has a particular nationality, personality and reaction to the culture in which this cross-cultural interchange is located. The kind of information that informants are willing to provide is heavily dependent on the nature of their interaction with the ethnographer. For that reason, it is necessary to take into account the attitudes and 
feelings of both parties in the dialogue, at least to the degree to which those experiences influence the nature of the information obtained. This means that another voice has to appear: that of the ethnographer qua normal human being. Here I am drawing on the distinction that Smadar Lavie (1990:37) makes between herself as an anthropologist and herself as a certain person reacting to the experience of living in a particular foreign culture. As Dorinne Kondo argues, knowing involves the whole self, not just the intellect, but 'these modes of knowing virtually disappear in the usual holistic, traditional anthropological monograph' (1986: 85). Thus self-reflexivity and a close scrutiny of the research process itself are crucial elements in ethnographies of experience.

A direct result of the focus on an individual's experiences as well as the integration of multiple voices, including that of the ethnographer, is the use of experimental textual strategies and formats. The older style of writing ethnography, with its typifying and distanced language, is clearly inadequate for a text that highlights individual experiences and multiple voices.

\section{Novel writing strategies used in Never in Anger}

The experimental textual strategies that Briggs employs in Never in Anger are both novel and novel-like. I argue that her use of narration and other techniques borrowed from the novel are particularly appropriate for her subject matter, the emotions.

In 1963-65, Jean Briggs spent seventeen months doing fieldwork among the Utkuhikhalingmiut - abbreviated to Utku in Briggs's book - north of the Arctic Circle, in Canada. She arrived in the community with a letter requesting that she be adopted as a daughter while doing her research. Living with an Utku family as a daughter proved to be extremely difficult for Briggs, and evidently for her 'family' as well. The Utku dislike of emotional volatility, their expectation that Briggs have the almost complete control over the expression of negative emotions that adult Utku have, and the requirement that Briggs submit 'unquestioningly' to her fictive father's decisions concerning her (1970:66) were particularly difficult. A serious misunderstanding arose. Briggs explains, 'I lost my temper (very mildly as we ourselves would view it) at some kapluna [i.e. white] fishermen who visited the inlet during the summer and who broke one of the Eskimo canoes' (1970:3). As a result, Briggs was ostracized, 'very subtly', for about three months. Though the Utku were outwardly solicitous of Briggs's physical needs, they no longer were willing to socialize with her. Briggs experienced deep depression. Several months 
later, when her fictive father was told about a letter explaining her anger that she had written to the head of the Anglican community of which the Utku were a part, there was a reconciliation.

Since Briggs was forced by circumstances to live and conduct her research in extreme proximity with and dependence upon her ethnographic subjects and, moreover since she was at the center of a traumatic experience both for herself and for the individuals with whom she lived, she was in an excellent position to research emotional patterning of the Utku. Her study centers on how Utku emotions are expressed, controlled, classified and taught to children. She demonstrated that Utku emotions are deeply embedded in elaborate belief systems and are closely tied to basic institutions of the culture: e.g. power relationships, kinship and religion. She presents her material in two forms, first as narrative accounts of events she witnessed that illustrate emotional patterning, and secondly as a detailed and systematic analysis of Utku terms for emotions (in a 55 page appendix). In both sections of the book, she shows how the Utku communicate aggression and affection and how an informal sanction system is used to control the expression of emotions. Her central conclusion is the sharp contrast between Utku emotional restraint and American volatility.

For Briggs, there is a strong connection between her subject matter, emotions, and her choice of narration as the primary vehicle for presenting her information. In a letter to me regarding this paper (22 October 1991), Briggs mentioned that the choice of writing style for Never in Anger was suggested to her by Cora DuBois. As author of the life-history The People of Alor, which, like Never in Anger, foregrounded the personal experiences of a few individuals in a culture, DuBois herself had grappled with issues of how to present personal experiences in an ethnographic text. However, it is clear that Briggs's decision to use the narrative style was not occasioned solely by the advice of the famous anthropologist but was consistent with her own ideas. Later in the same letter, Briggs referred to her conviction that the narrative style is particularly well-suited to conveying emotions of ethnographic subjects. Commenting on a book that she is presently writing, she states, 'I've found that the emotionally powerful "interpersonal dramas" . . . are unreadable, ungraspable, unless I first present them in narrative form, "Never in Anger form".' The following passage from Never in Anger, about Raigili, aged six, her younger sister Saarak, aged three, and their mother, Allaq, is typical of the way in which Briggs sets forth the emotions of her subjects.

Though often it was impossible to guess what visions caused Raigili to shriek out in her sleep, there was one night when her woe was quite explicitly expressed. Bedtime had not been peaceful that night. Allaq had, as usual, 
undressed Saarak with coaxing endearments (aqaq), whereas Raigili, her arms withdrawn in fatigue, had sat silent, motionless and ignored, in her place on the ikliq. This was the first winter in which Raigili had been expected to undress herself, and the expectation was too much for her when she was tired. For a while her unvoiced request for help received no response; but eventually, with protest in the brusqueness of her touch and in her characteristic mooing murmur of disapproval, Allaq did pull off Raigili's tight boots and fur trousers, fold her clothes into a pillow, and settle her under the quilts beside Saarak. 'Your little sister can take off her boots better than you can,' Allaq mooed at Raigili. Almost immediately Saarak broke into a wail and Allaq chided Raigili: 'Raigili annoys (urulu) her little sister.' Raigili, her cheeks wet with silent tears, fell asleep. Suddenly she reared up, as she always did in her nightmares, her body tensed into an arc and her head weaving, emptily searching from side to side as she wailed over and over: 'Mother, mother! Bad bad Saarak! I'm bad, bad! Saarak is bad! I'm bad!' She was, as always, frozen in her vision; it was impossible to wake her. . Eventually, without waking, Raigili, her cries fading into whimpers, subsided onto her pillow and slept quietly. (1970: 145)

Briggs's primary strategy to convey the emotions of the three ethnographic subjects is the use of narration. In many English-speaking cultures (the public for which Briggs's book is written), reading a story is a particularly pleasing way of obtaining information because of its links to warm and intimate childhood settings in which stories were read or told and because of its associations with art forms intended to relax or entertain, such as novels and movies. Stories bring pleasurable expectations of problem presentation, climactic conflict and denouement. This structure is also satisfying because of its sense of closure. By using narration, Briggs accomplishes several goals. (1) She grabs our attention because of the pleasant associations the narrative form has for us. (2) She inspires the readers to feel the subjects' emotions as their own, because storytelling in our culture usually involves the development of characters with whom the reader is expected to empathize. (3) She highlights her focus on children by choosing a medium that is associated, at least in part, with children. Briggs signals the start of a story with 'there was one night when ... . She moves from the problem (the conflict between Raigili and her mother) to the resultant climax (the nightmare) and to the closing disappearance of tension (Raigili 'slept quietly'). The narrative structure allows us to sense a whole range of shifting emotions that Raigili and Allaq feel as they interact with one another in this scene. For example, at first, Raigili is dejected and withdrawn, then grief-stricken, then angry at herself and at Saarak, then unable to interact with the world.

Another literary technique that Briggs uses to convey the conflict of 
emotions in this passage is the use of oxymorons and contradictions. Such expressions as 'shriek out in her sleep,' 'bedtime had not been peaceful' (for preparation for sleep is usually a time of lessening of tension), 'unvoiced request', 'silent tears' (for tears are usually accompanied by sounds) and 'frozen in her vision' are emblematic of the several emotional conflicts that are at the core of the passage: the contest between Raigili and her mother, the contrasting emotions that Allaq displayed in her treatment of Saarak ('coaxing endearments') and Raigili ('mooing murmur of disapproval') and most importantly the contrast between aqaq and urulu, the only Utku terms used in the passage. In her appendix, Briggs defines aqaq as the 'cooing' showered on children who are at the age when adults cuddle and kiss them. Urulu, meaning annoyance, is, among adults, used only in the third person, because an Utku does not want to admit that he himself is angry nor accuse others of this negative emotion. Since by Utku standards, Allaq could not say that she felt annoyed, she stated, in the third person that Raigili inspired this negative emotion in Saarak. The use of these two Utku terms in close proximity highlight the main theme of both the passage and of the book: while expressions of affection are encouraged by the Utku, expressions of anger 'never' are.

Silence and noise constitute another contrasting pair in this passage, and they point to another basic theme in Utku culture. In the beginning, Raigili was 'silent, motionless and ignored', with an 'unvoiced request'. As Allaq came into open conflict with her, sounds were heard: 'mooing murmur of disapproval', Allaq's verbal condemnation of Raigili, Allaq's 'chiding', and Saarak's wail. This was followed by more silence on Raigili's part, but one that speaks of intense emotion: 'silent tears'. In sleep, perhaps somewhat removed from Utku prohibitions against expressing negative emotions, Raigili's silence suddenly exploded into loud repeated wails of self-recrimination and anger. This contrast between silence and sounds may point to a basic tension in Utku culture: one may have intense emotions, but they have to remain silent, or 'frozen'. Silence may also index another key Utku concept: hujuujaq. Usually translated as 'loneliness', this term also includes feelings of unhappiness, depression and distress. Feelings of hujuujaq are, according to the appendix (1970:355), often associated with unpleasant cold and wet weather, autumn darkness or hunger. Briggs notes that loneliness is a 'salient experience for Eskimos generally', that they talk about it frequently, and that they try to prevent others from feeling it (1970: 354-55). The emphasis on silence and sounds in this passage highlights the Utku notion that if one expresses intense negative emotions (especially anger), one faces silence, loneliness and rejection. Indeed, these were the sanctions levied against Briggs when she 
openly voiced her anger to the kapluna fishermen. My point here is not so much to provide an explication de texte but to show how some of Briggs's writing techniques, in this case narration and the use of contradictory phrases, make manifest both the emotions of the characters and the intimate links of those emotions to basic tenets of the culture.

Connected to her reliance on narration there are other techniques borrowed from the novel. The first is the use of the everyday language of emotions (both English and Utku), rather than the abstract Latin-derived terms and the generalizing and distancing language of social science. Her choice of language is particularly felicitous since her topic is the expression of emotions. She chose a language filled with references to her own and her subjects' emotions, and a language that is designed to arouse our emotions. The second novel-like technique is the focus on the particularities of others' experiences (rather than on cultural rules). Both of these techniques embrace the reader in the story, allowing her/him to feel closer to the individuals in Briggs's community than she would feel if the emotions were described as autonomous notions, divorced from living persons. We, the readers, see the ethnographic subjects not as interesting though distant aliens, but as very much like ourselves, as embodiments of ourselves born into a different culture. Third, the language that Briggs chooses is strikingly vivid. Briggs employs this evocative writing style in a self-conscious attempt to draw the reader into the world of the informants. She states, 'I hope . . . to present the material vividly enough so that the reader, sharing to some extent my cultural background, can also experience empathy and contrast between his feelings and those of Utku. . .' (1970: 6).

\section{Self-reflexivity in Never in Anger}

Perhaps the most experimental element in Briggs's style and one that ties it closely to the new ethnographies of experience is her inclusion of her own reactions to her research situation. What purpose did Briggs's remarkable openness serve? There are several answers to this question.

First, her self-reflexivity is justified because she herself was an integral part of the research situation. Her reactions to her circumstances caused some of the most traumatic emotional outbreaks among the Utku recorded in the book. The reader learns as much about the Utku as about Jean Briggs when she describes her responses to them. For example, when she angrily rebukes the kapluna fishermen in an effort to protect her Utku friends, we learn about Utku dislike of expressed anger.

Second, understanding the emotions of individuals in another culture involves a comparison, implicit if not explicit, with one's own emotions and 
the ways emotions are handled in one's own culture, as Catherine Lutz notes (1988:12). As one becomes painfully aware of the differences in emotional responses between oneself and those of the ethnographic subjects, one naturally asks, 'How are these people like me and how are they different?' Briggs was acutely aware of this issue. She states, '. . . my own reactions to the situations in which I found myself - my empathy and my experience of contrasts between my feelings and those of my hosts were all invaluable sources of data' (1970:6).

Third, I suggest that Briggs chose to include her own reactions because she wanted her readers not only to understand Utku emotions from an intellectual point of view, but to feel their emotions, to empathize with the Utku. One way in which she accomplished this was to reveal to us her own emotions. Since she presented herself as a real person (vulnerable, fallible, emotional, loving, intensely disliking), we empathize with her. We see ourselves in her shoes, and this allows us to experience the Utku as she did, as real humans.

To make my point clearer, let us imagine a book about Utku emotions in which the author did not choose to reveal her/his own reactions regarding the Utku. In such a book, there would be a strong tendency for the author to adopt an omniscient, detached stance, as if voyeuristically peering into the Utkus' private lives and parading their emotions before us as though they were completely foreign to our experience of ourselves and our friends as emotional beings. Renato Rosaldo has written about the problems that the lack of self-reflexivity has created in various classical ethnographies about death:

Unreflective talk about culturally expected expressions of grief easily slips into skepticism about the reality of the emotions expressed. It is all too easy to elide the force of conventional forms of life with the merely conventional, as if forceful emotions were mere motions. . . . Even eyewitness reports cast in the normalizing ethnographic idiom trivialize the events they describe by reducing the force of intense emotions to spectacle. (1989:58)

By providing a vision of the Utku from the perspective of one person (herself), Briggs has made Utku emotions vivid and believable for her readers.

Fourth, Briggs's self-reflexivity is a product of her decision to focus on deviant emotional behavior. She emphasized misbehavior in order to cast good behavior into sharp relief and to show the ways in which such behavior is controlled. The 'deviants' who were available for Briggs to study were children, adult Utku who exhibited personality characteristics considered unpleasant by Utku standards, and foreigners. Briggs was the 
foreigner with whom the Utku had the closest contact, in Briggs's experience. In a recent letter on this subject, Briggs wrote to me that her own world-view 'was - intentionally - in focus only to the extent that it interfered with the smooth flow of Utku life' (personal communication, 22 October 1991). Her self-reflexivity was not an indulgent display of her feelings and experiences, but rather an integral aspect of her scholarly goal: to clarify Utku emotions.

\section{Issues of ethnographic authority in Never in Anger}

Briggs's use of self-reflexivity and her avoidance of the standard language of generalizations are connected in interesting ways to ethnographic authority. Her focus on the emotions and experiences of the important individuals in her research setting, namely her informants as well as herself, resulted in a rejection of the standard language of generalizations. Abu-Lughod (1993: 8) ${ }^{1}$ notes that the language of generalizations is not the detached, objective and neutral discourse it is assumed to be. On the contrary, it is a language of power because historically it has been the professional discourse of those in positions of power, such as managers, administrators and other professionals who controlled oppressed social groups like workers, women, blacks, the poor or prisoners. In the field of anthropology, the language of power has been exacerbated by the colonial-style relationships that anthropologists typically had with their subjects (and of course the ethnographic terms themselves reflect the unequal power relations of ethnographers and their subjects). By eschewing the language of generalizations, by using instead a language filled with detailed descriptions of her own emotions and those of her informants, Briggs refused to depict herself as an all-knowing, powerful theorist and scholar of Utku culture. For the most part, she put herself on an equal footing with her informants.

Briggs's willingness to share ethnographic authority with her informants is evident not only in her choice of language, but also in the kinds of relationships she had with her informants. While her main motivation for including her own reactions to the research situation stemmed from her scholarly goals, she had other motivations as well. By examining those motivations, we can see how ethnographic authority moved from the anthropologist to informants and back again.

By openly expressing her feelings about her experiences with the Utku, Briggs could demonstrate both her gratitude to her Utku hosts and her regrets that she could not behave in the way they expected her to. She states, 'When I think of Inuttiaq [her fictive father] now, my feelings are a 
complex blend of admiration, affection, gratitude, and a helpless desire to compensate him somehow for the difficulties that my un-Eskimo behavior caused' (1970: 41).

Perhaps, at some level, conscious or unconscious, she wanted to arouse the reader's and her own sympathy for her difficult plight, because she needed their and her own forgiveness, in order to feel freed from her feelings of unease for the way she behaved with the Utku. Such feelings would be natural given the extreme emotional trauma that she underwent during the three months of ostracism. I believe that she suffered a 'fragmentation of self' much like the one that Dorinne Kondo (1986), who was also adopted as a daughter, experienced doing fieldwork in Japan. That near collapse of identity, Kondo explains, is the product of the 'violence' inherent in the anthropological enterprise. ${ }^{2}$

'Violence' in anthropological encounters is usually attributed to researchers who, through a process of establishing rapport, manipulate informants to obtain data. They then abandon them and divest them of authority by controlling the written product. However, Kondo notes that 'violence' sometimes works in the opposite direction, with informants 'seeking to dominate the anthropological encounter through control of the ethnographer's behavior' (1986: 80).

Briggs's experience of 'fragmentation of self' was engendered, at least partially, by the pressures exerted on her by Utku culture. As a result of those pressures, she may have behaved in ways that caused pain to her fictive Utku parents. Her resulting need for forgiveness was exacerbated by another factor, her self-image as a child. Anthropologists share many of the characteristics of children when they do fieldwork in a foreign culture. They cannot live up to the behaviors expected of adults in that culture, and they frequently have limited power in determining how they should behave. In addition, anthropologists, like children, make mistakes and seek forgiveness from the people who have so much power over them.

In many ways, Briggs depicts herself as powerless and dependent in her book, though of course, for the most part, she presents herself as a professional anthropologist. At one point, she admits, 'I enjoyed the solicitude of my Utku parents and my own childlike dependence' (1970: 249). That she at times felt like a child is perfectly understandable. She did not know the language, the social behavior expected of her, the skills that an adult Utku woman would have (e.g. harnessing a dog-sled). Furthermore, she was living in an extremely hostile climate where she was completely dependent on her hosts for her very survival. Her selfpresentation or perhaps even self-image as a child while in the field is important because a child has only limited power to withstand the demands 
of others. A child is particularly vulnerable to others' criticisms and to feelings of guilt if she does not follow the adult's wishes. I believe that Briggs felt that way for she states,

'I felt his [Inuttiaq's] solicitude was prompted partly by a wish, conscious or unconscious, to foster in me feelings of obligation. When he was so fatherly he left me no alternative but to want to be daughterly - or to be needled by guilt when I could not be. $(1970: 66)^{3}$

Her guilt for having caused the Utku problems and her gratitude to them for tolerating her as much as they did all found release in the ethnography she produced. Kondo comments that the writing of the ethnographic text accomplishes the 'reconstitution of self'. 'Writing thus becomes a way of freezing the disturbing flux, encapsulating experience in order to control it' (1986: 82). It now becomes clear why Briggs chose the title she did. 'Never in anger' has multiple referents, pointing to Utku emotional training, which places high value on the control of negative emotions; to Briggs's personal story, which, to a large extent, involves the repression of her own anger; and to her catharsis in writing the book in which her repressed feelings were discharged and dissolved.

The openness with which Briggs writes about her vulnerabilities and weaknesses casts into sharp relief issues of ethnographic authority. In some ways, she was disempowered, under the control of her Utku parents, who were, in Kondo's terms, engaging in a kind of 'violence' in their dealings with Briggs. However, perhaps the 'violence' also moved in the other direction, from the ethnographer to the informants. Briggs was in some ways blind to her hosts' needs. Her colonial assumption of her right to conduct research with the Utku is indicated by her decision to allow herself to be dropped off at the Utku site, unannounced, with no way of getting back home for three months. It is true that the idea of adopting this plan was initially not her own, but was suggested to her by the wife of the head of the Anglican community in Goja Haven. She counseled Briggs to withhold the letters explaining her presence until after her plane had left. In a letter to me on this subject (23 February 1992), Briggs stated,

'I recall feeling somewhat alarmed at the idea, but it didn't occur to me to question her judgment, as she was an Inuk. But, wiser the second time and forever after, I've done it differently, giving Inuit plenty of opportunity to look me over before committing themselves to my presence for an extended period of time.

Her occasional incognizance of Utku needs is also indicated by her lack of awareness of the burden that her physical possessions posed for the Utku. She states, 
It was only after I had returned to my own country that I saw, in my photographs of a spring move, the contrast between Inuttiaq's sled load and Ipuituq's, the latter little over knee high, the former shoulder high. At the time, I was blind. (1970: 247)

Connected to issues of ethnographic authority are the shifting feelings of empathy that, I surmise, Briggs felt for her hosts. While in the field her feelings of empathy were occasionally dulled, upon return home those feelings became dominant, and thus her text contains great empathy and warmth. I suggest that the delayed expression of empathy towards the Utku can be explained by a complex of related factors. She regretted her inability to be the daughter the Utku expected, so she wrote a book full of empathy, almost apology, in compensation. During the writing of the ethnography, Briggs at last had complete control over her work situation; she could 'reencounter the Other "safely"' (Kondo, 1986: 82). She could be the dutiful daughter, without risk to her identity as an anthropologist. Freed from feelings of guilt, she regained her sense of authority. Defensiveness is another element in the explanation, as Briggs herself suggested.

In the field I felt empathy when I was not personally in conflict with other people. When I was in conflict I felt defensive . . . I think the lifting of the defensive shield was more important than 'guilt' in determining the empathy I felt after I got home. (personal communication, 23 February 1992)

\section{Reception history of Never in Anger}

Self-reflexivity in Never in Anger is closely tied to the history of its reception. How was Never in Anger regarded when it was published in 1970 , and how has it been evaluated since then? The answer to these questions can be ascertained by examining how emotions and personality were studied by anthropologists and psychologists during the decades leading up to the publication of Never in Anger.

In the 1930 s through the 1950 s, anthropologists tended to believe that personality was formed largely by cultural conditioning. One of the primary goals of anthropological research was to demonstrate how personality mirrors the larger culture (Ruth Benedict, Margaret Mead, Edward Sapir and C.G. Seligman). The national character studies of Mead and the modal personality studies of DuBois are examples of this approach. Techniques used were largely objective and test-oriented in line with the then-popular methods in experimental psychology. For example, in The People of Alor, DuBois set out to demonstrate that there is a relationship between the personality of adults in a group and the culture in 
which they live. In order to do this, she attempted to define the central elements in the personalities of a group of people. Her methodology for achieving this goal included the administration of Rorschach tests and Porteus maze tests.

While anthropology in the 1930s placed greater emphasis on culture than on universal human structures in explaining personality formation, psychoanalysts at the time tended to assume that culture was a product of universal, though unconscious, structures inherent in the human mind. Most important of these basic structural forces, they held, was the Oedipus complex as articulated by Freud. By the 1950 s and 1960 s, some anthropologists, for example DuBois and Roheim, had become influenced by Freudian assumptions of the universality of unconscious forces. In his book Psychoanalysis and Anthropology: Culture, Personality and the Unconscious (1950), Roheim analyzes anthropological materials using Freudian methods.

This, then, was the picture when Briggs set out to write her book: some anthropologists - among them DuBois, Briggs's thesis advisor and one of the persons to whom the book is dedicated - and most psychoanalysts believed that some, if not all, aspects of personality formation could be explained by basic, universal human drives. How do emotions fit into this picture? Catherine Lutz notes that

the Western view of emotion [is] predicated . . . on the belief that emotion is in essence a psychobiological structure and an aspect of the individual. The role of culture in the experience of emotion is seen as secondary, even minimal, from that perspective. $(1988: 4)$

Lutz goes on to credit Briggs for being the first anthropologist to show that emotions are deeply embedded in complex cultural systems, and that they are tied to local meanings, rather than to universal psychobiological structures. ${ }^{4}$ This is not to say that there are not some universalistic tendencies in some of Briggs's assumptions about emotions.

According to Lutz, Briggs, along with Robert Levy and Michelle Rosaldo, helped found the field of ethnopsychology. Evidently other scholars do not see Never in Anger as seminal as does Lutz. The paucity of reviews and references to the book in works on ethnopsychology and psychological anthropology suggest that for the most part Never in Anger has not been regarded as a serious contribution to either sub-discipline. With the exception of two references (one by Lutz), none of the following currently influential works in psychological anthropology mention Briggs's book - The Makeup of Psychological Anthropology by George D. Spindler 
(1978), Person, Self, and Experience: Exploring Pacific Ethnopsychologies, by Geoffrey White and John Kirkpatrick (1985) and Language and Socialization across Cultures by Schieffelin and Ochs (1986).

Five reviews of Never in Anger have been published in professional journals. It is significant that only one of these reviews was published in an anthropological journal. The others appeared in journals about the Arctic, psychiatry or social work. The authors of these four reviews regarded Briggs's inclusion of her own reactions as an integral part of her scholarly task, rather than merely part of a project to report autobiographically on fieldwork experiences (see Vallee, 1971; Shiloh, 1971; Leighton, 1971; Prince, 1972). In contrast, Zachary Gussow, author of the one review published in a scholarly journal of anthropology (American Anthropologist), regarded her book primarily as an account of her fieldwork experience.

Unfortunately, in its present form the data are neither sufficiently systematized nor sufficiently analyzed to be of much value for comparative purposes, nor do they provide a coherent framework for understanding Eskimo emotional life. From this perspective, the work is difficult and often frustrating to read; however, if one chooses at first to read it differently, as one might read a novel, it is fascinating, informative, and very human. . . . The narrative style, which is ill-suited for cultural description and generalizations, can be a delicate device for conveying, at the gut level, what a long and difficult field trip means to all parties involved in the encounter. (1972: 871)

In another part of the review, he regretted that Briggs included Utku terminology for emotions in her narrative, as if the point of the book were the narrative of her personal experience.

Briggs's use of self-reflexivity as an integral part of her scholarly task was somewhat ahead of her time. Openness and self-reflexivity in scholarly works in anthropology were relatively unusual in 1970 when Never in Anger was published. Renato Rosaldo (1989:25-45) divides twentiethcentury anthropological research into two periods: the 'classic period', starting in about 1921 and the contemporary period starting in about $1971 . .^{5}$ He notes that works in the classic period were characterized by a discourse that was elevated, distanced and normalizing; self-reflexivity was not encouraged. Only recently has inclusion of one's personal reactions in scholarly anthropological works begun to be acceptable, as evident in the works of Vincent Crapanzano (1980), Kevin Dwyer (1982), Dorinne Kondo (1986 and 1990), Renato Rosaldo (1989) and many others. Even by today's standards, the inclusion of the ethnographer stands out in Briggs's 
text. Many scholars are still resistant to the subjective style, as Rosaldo notes.

It is striking that even some current anthropologists who use selfreflexivity in their writing or applaud others' use of it do not cite Never in Anger. Perhaps they, like Gussow, consider her book primarily an account of fieldwork. Marcus and Fischer (1986: 69) label it 'a good account of field experience' that is concerned with 'learning to control expressions of aggression and irritation'. It is clear from the context that the subject of this clause is the anthropologist herself, not ethnographic subjects. Despite the fact that Crapanzano (1980), James Clifford (1983), Dorinne Kondo (1990) and Kevin Dwyer (1982) speak explicitly of the value of selfreflexivity, they do not refer to Never in Anger. However, Rabinow (1977), Clifford and Marcus (1986), Abu-Lughod (1986, 1993) and Behar (1993) do mention it as an early example of self-reflexivity in ethnographic writing.

The assessment of Never in Anger may be changing. The more recent texts, as indicated above, do cite it. In 1989, Renato Rosaldo wrote that he regarded Briggs's presentation and analysis of her own emotions as an essential element in her research strategy (1989:174-79). Furthermore, several of the authors in both New Directions in Psychological Anthropology (edited by Schwartz, White and Lutz, 1992) and Culture Theory: Essays on Mind, Self and Emotion (edited by Shweder and Levine, 1984) mention Never in Anger as an important scholarly contribution to studies of emotion, socialization, language, meaning and ethnopsychology in general.

Why has Never in Anger been neglected as a scholarly work? There are several possible explanations. First, it espoused a culture-based theory of emotions at a time when emotions were (and for the most part still are) regarded by anthropologists, psychologists and Western thought in general as natural, universal and irrational. ${ }^{6}$

Second, it was assessed, inaccurately I submit, as an ego-centered record of fieldwork. This, in turn, requires explanation. Published before the other major ethnographies that combine self-reflexivity with cultural analysis, Never in Anger may have got lost in the cracks, so to speak, when participant observation was replaced by what Barbara Tedlock calls 'the observation of participation' (1991:78) - or what I have called selfreflexivity. Also, it was viewed as an account of fieldwork because it eschewed the current scientific mode of expression. Rather, the writing style is novelistic, with vivid descriptions, trenchant character development and poignant narratives. That it was written by a woman in a semi-autobiographical mode may be another reason for its relegation to 
the lower-status category of fieldwork account. Julia Swindells notes the low status of autobiographies written by women in our culture. They are considered solipsistic, for they 'claim the personal (limited and inferior) as the social (superior and broad)' (1989:28). Third, the near-erasure of Never in Anger is partly due to its focus on emotions, children and child-rearing, all of which have, for the most part, until recently been neglected by anthropologists. ${ }^{7}$

In 1981, Theodore Schwartz noted that 'anthropology had ignored children in culture while developmental psychologists had ignored culture in children' (1981: 4). Since emotions are regarded in American culture as belonging primarily to the female realm (Lutz, 1988:376), and since women and their activities (especially child-rearing) have been considered unworthy of close anthropological investigation, it is not surprising that Never in Anger has been relegated to the margins of the anthropological canon.

Although I have stressed that Never in Anger has generated remarkably few citations in scholarly anthropology works, it has sold extraordinarily well for an academic book. According to Briggs, by December 1992, more than 42,000 copies had been sold. Most of these sales were made during the 1970s and early 1980s, when the book was largely being ignored or misunderstood by the academic community. Briggs wrote in a recent letter to me (21 April 1993),

I suppose many of the buyers were first year anthropology students, who were reading it as an example of 'fieldwork'. If this is so, it might support your view that the book has not been treated as a scholarly work. On the other hand, I have over the years, received quite a lot of anthropological recognition - entirely on the basis of my connection with Never in Anger. . .

\section{Conclusion}

In sum, Never in Anger has many of the characteristics of an ethnography of experience. Its focus is on the emotions, experiences and complex feelings of a few individuals. The viewpoints of several Utku are richly represented, even when they are at variance with those of the author. Thus the reader is in a position to understand the Utku from a variety of perspectives. The inclusion of multiple voices highlights issues of ethnographic authority, as Briggs and the reader shift in their assessments of who had authority: informants, Briggs qua anthropologist or Briggs qua human being responding to lived experience. Since the Utku's emotional reactions to Briggs were a valuable source of data and since those feelings are intimately tied to her responses to them, both the Utku feelings and 
Briggs's reactions are sharply defined. For that reason, self-reflexivity is an integral element in the work. The need to present in an evocative way the intense and shifting emotions of a variety of individuals interacting together resulted in the use of an unusual textual format, storytelling. With its links to childhood and its capacity to inspire the reader's sense of empathy, narration is perfectly suited to a study of emotions that features children and other dependents. Unfortunately, several of the best elements of the book, its focus on topics that were at the time out of favor in anthropology, such as emotions and children, its use of literary techniques borrowed from novels, its avoidance of the standard scientific generalizing and distancing language, its self-reflexivity, and its shifting ethnographic authority have led many people to misconceive the book simply as an account of fieldwork rather than as a founding contribution to the field of ethnopsychology and as a pathbreaking ethnography of experience.

\section{ACKNOWLEDGMENTS}

I want to thank Ruth Behar for taking the enormous time and energy to organize a conference around the issues of women and anthropology that grew out of her graduate seminar 'Women Writing Culture' and for reading and commenting extensively on many drafts of this paper. I am also indebted to Jean Briggs, who read three drafts of the paper and sent me extensive critiques of them. Amy L. Heffernan and Catherine A. Lutz also made many helpful contributions.

\section{NOTES}

1. Abu-Lughod draws on Dorothy Smith (1987) for this analysis.

2. Kondo (1986) notes that several scholars (Rabinow, 1977; Crapanzano, 1980; Reinharz, 1979) have characterized anthropology as 'violent'.

3. In some ways, Briggs's ability to take on the role of a dependent, powerless person worked to her advantage. Reacting to this section of my paper in her letter of 22 October 1991, Briggs wrote,

I would add that allowing oneself to be guided by others' views and/or decisions when in the field might be seen not only as evidence of a 'childlike' self-image but also as a sign of mature wisdom - an ability to flow with the tide and learn from the people one has come to learn from.

4. By placing as much emphasis as she does on child-rearing practices, she reflects the Freudian notion that critical events in childhood mould the adult character.

5. In her analysis of the emergence of the use of self-reflexivity in ethnographies, Barbara Tedlock (1991) corroborates the basic outlines of Rosaldo's history, but 
she divides the timespan into three periods. The 1930 s to the 1950 s saw the publication of a few ethnographies (such as Reichard, 1934 and Marriot, 1952) that combined personal accounts of fieldwork with ethnographic information. In the 1960s and 1970s, fieldwork accounts - such as Rabinow (1977) and Dumont (1978) - were published separately from ethnographies. In such accounts, the author's character and experiences took center stage, while those of cultural 'others' were less weil developed. The 1970s and 1980s witnessed a major shift to 'narrative ethnography', in which ethnographic subjects were fully developed as characters, and the author was included to the extent necessary to delineate those characters or to explain the dynamics of the relationship between the ethnographer and the ethnographic 'others'. While Tedlock places Never in Anger in the second category, I argue that it should be seen in the third category.

6. See Lutz (1988) for a detailed discussion of how Western thought regards emotions.

7. There are important exceptions to this disregard, e.g. Margaret Mead's interviews with Manus children in 1928 (1932).

\section{REFERENCES}

Abu-Lughod, Lila (1986)

Veiled Sentiments: Honor and Poetry in a Bedouin Society. Berkeley: University of California Press.

Abu-Lughod, Lila (1993)

Writing Women's Worlds: Bedouin Stories. Berkeley: University of California Press.

Behar, Ruth (1993)

Translated Woman: Crossing the Border with Esperanza's Story. Boston: Beacon Press.

Briggs, Jean L. (1970)

Never in Anger: Portrait of an Eskimo Family. Cambridge, MA: Harvard University Press.

Briggs, Jean L. (22 October 1991)

Letter to Susan Pratt Walton.

Briggs, Jean L. (23 February 1992)

Letter to Susan Pratt Walton.

Briggs, Jean L. (21 April 1993)

Letter to Susan Pratt Walton.

Bruner, Edward M. (1986)

'Experience and its Expressions', in Victor W. Turner and Edward M. Bruner (eds) The Anthropology of Experience (pp. 3-30). Urbana: University of Illinois Press.

Clifford, James (1983)

'On Ethnographic Authority', Representations 1:118-146. 
Clifford, James and George E. Marcus, eds (1986)

Writing Culture: The Poetics and Politics of Ethnography. Berkeley: University of California Press.

Crapanzano, Vincent (1980)

Tuhami: Portrait of a Moroccan. Chicago: University of Chicago Press.

DuBois, Cora (1944)

The People of Alor: The Social-Psychological Study of an East Indian Island. Minneapolis: University of Minnesota Press.

Dumont, J.P. (1978)

The Headman and l: Ambiguity and Ambivalence in the Fieldworking Experience. Austin: University of Texas Press.

Dwyer, Kevin (1982)

Moroccan Dialogues: Anthropology in Question. Baltimore: Johns Hopkins University Press.

Gussow, Zachary (1972)

'Review of Never in Anger by Jean Briggs', American Anthropologist 74(4): 870.

Kondo, Dorinne K. (1986)

'Dissolution and Reconstitution of Self: Implications for Anthropological Epistemology', Cultural Anthropology 1(1): 74-88.

Kondo, Dorinne K. (1990)

Crafting Selves: Power, Gender, and Discourses of Identity in a Japanese Workplace. Chicago: University of Chicago Press.

Lavie, Smadar (1990)

The Poetics of Military Occupation: Mzeina Allegories of Bedouin Identity Under Israeli and Egyptian Rule. Berkeley: University of California Press.

Leighton, Dorothea C. (1971)

'Review of Never in Anger by Jean Briggs', American Journal of Psychiatry 127: 11.

Levy, Robert (1973)

Tahitians: Mind and Experience in the Society Islands. Chicago: University of Chicago Press.

Lutz, Catherine A. (1988)

Unnatural Emotions: Everyday Sentiments on a Micronesian Atoll and Their Challenge to Westem Theory. Chicago: University of Chicago Press.

Marcus, George E. and Michael M. Fischer (1986)

Anthropology as Cultural Critique: An Experimental Moment in the Human

Sciences. Chicago: University of Chicago Press.

Marriot, A. (1952)

Greener Fields: Experiences among the American Indians. Garden City, NY: Doubleday.

Mead, Margaret (1932)

'An Investigation of the Thought of Primitive Children, with Special Reference to Animism', Joumal of the Royal Anthropological Institute 62: 173-90.

Prince, Raymond (1972)

'Review of Never in Anger by Jean Briggs', Canadian Psychiatric Association Journal 17: 258. 
Rabinow, Paul (1977)

Reflections on Fieldwork in Morocco. Berkeley: University of California Press.

Reichard, G.A. (1934)

Spider Woman: A Story of Navajo Weavers and Chanters. New York: Macmillan.

Reinharz, Shulamit (1979)

On Becoming a Social Scientist. San Francisco: Jossey-Bass.

Roheim, Geza (1950)

Psychoanalysis and Anthropology: Culture, Personality and the Unconscious. New York: International Universities Press.

Rosaldo, Michelle Z. (1980)

Knowledge and Passion: llongot Notions of Self and Social Life. Cambridge: Cambridge University Press.

Rosaldo, Renato (1989)

Culture and Truth: The Remaking of Social Analysis. Boston: Beacon Press.

Schieffelin, B.B. and E. Ochs eds (1986)

Language Socialization across Cultures. Cambridge: Cambridge University Press. Schwartz, Theodore (1981)

'The Acquisition of Culture', Ethos 9(1): 4-17.

Schwartz, Theodore, Geoffrey M. White and Catherine A. Lutz, eds (1992)

New Directions in Psychological Anthropology. Cambridge: Cambridge University Press.

Shiloh, Ailon (1971)

'Review of Never in Anger by Jean Briggs', Social Casework Journal 52: 472.

Shweder, Richard and Robert Levine, eds (1987)

Culture Theory: Essays on Mind, Self, and Emotion. Cambridge: Cambridge University Press.

Smith, Dorothy (1987)

The Everyday World as Problematic. Boston: Northeastern University Press.

Spindler, George D., ed.(1978)

The Makeup of Psychological Anthropology. Berkeley: University of California Press.

Swindells, Julia (1989)

'Liberating the Subject: Autobiographies and Women's History: A Reading of the Diaries of Hannah Cullurik', in The Personal Narratives Group (ed.) Interpreting Women's Lives: Feminist Theory and Personal Narratives, pp. 24-38. Bloomington: Indiana University Press.

Tedlock, Barbara (1991)

'From Participant Observation to the Observation of Participation: the Emergence of Narrative Ethnography', Journal of Anthropological Research 47(1):6994.

Turner, Victor W. and Edward M. Bruner, eds (1986)

The Anthropology of Experience. Urbana: University of llinois Press. 
Vallee, Frank G. (1971)

'Review of Never in Anger by Jean Briggs', Arctic 24(3): 238-239.

White, Geoffrey and John Kirkpatrick, eds (1985)

Person, Self, and Experience: Exploring Pacific Ethnopsychologies. Berkeley: University of California Press. 